\title{
Women and Economic Production: Towards Sustainable Livelihoods in Zimbabwe
}

\author{
Tafadzwa Clementine Maramura ${ }^{1}$, Dovhani Reckson Thakhathi ${ }^{1}$ and \\ Happy Mathew Tirivangasi ${ }^{2, *}$
}

\author{
${ }^{1}$ Department of Public Administration, University of Fort Hare, Faculty of Management and Commerce, South \\ Africa \\ ${ }^{2}$ Department of Research Administration and Development, University of Limpopo, P. bag X1106, Sovenga, \\ 0727, South Africa
}

\begin{abstract}
Persistent drought and economic collapse in Zimbabwe have seen most, if not all, rural women shifting from the receiving end to the giving end. Rural women have since initiated several livelihood activities to make ends meet, as they are the most vulnerable whenever they are left to look after children at home. The paper aims to examine rural livelihoods and how they contribute to economic production in Ward 5 of Bikita district. A mixed design in the form of a case study was employed in this study. Systematic random sampling was used to select 40 households, which provided data for the study out of 409 households in Ward 5. The study used questionnaires and semi-structured interviews as data collecting instruments. Several livelihood activities were noted in the ward including seasonal farming, gardening, community-based and money lending and saving schemes (fushai), informal trading, and petty trading as selling thatch grass and firewood, among others. However, climate change and drought, economic crisis, lack of capital and poor soils and poor farming methods were some of the constraints faced in rural livelihoods. The paper concludes with several recommendations for eradicating rural livelihood challenges.
\end{abstract}

Keywords: Rural Women, Poverty, Resilience, Livelihood, Sustainable Economy.

\section{INTRODUCTION}

Zimbabwe experienced shocks and stresses during the post-colonial era like persistent droughts, ESAP and the 2008/9 economic failure with the rural populace affected most (Poverty Reduction Forum Trust [PRFT], 2013). The majority of men, believed to be the heads of families in the African tradition, migrated from rural areas to urban areas with some leaving Zimbabwe in search of employment (Buckland, Eele and Mugwara, 2000). Rural women shouldered the burden of being breadwinners and major decision-makers in the absence of men (PRFT, 2013). This was a major shift for many households, being patriarchal societies; women relied on men to make major decisions in the family. This scenario have seen rural women shifting from the receiving end to the giving end (Muzvidziwa, 2000). Rural women are involved in economically productive activities in form of various livelihoods such as, gardening, pottery making, cross-boarder trading, irrigation farming, buying and selling of second-hand items and clothes (mabhero), informal employment (maricho) and more (Mushore, Muzenda and Makovere, 2013). Women have a stake in the up keeping of children as they take part in various forms of livelihood activities which assure them of food on their tables (Mathew, 2003). Some rural women have

*Address correspondence to this author at the University of Limpopo, P. bag X1106, Sovenga, 0727, South Africa; E-mail: mathewtirivangasi@gmail.com contributed much to the country's economy through informal trading; hence they are industrious (Matthew, 2003).

Rural women have initiated several livelihood activities as an answer to the ever-growing need to alleviate poverty and hunger in their households (Muzvidziwa, 2000). The resilience of rural livelihoods now dependent most on women, which entails that rural women should be empowered to make decisions that have a positive impact on livelihoods and wellbeing of families without relying too much on men. Studies by International Labour Organization (ILO) (1998) indicated that women contribute to the economy and to poverty alleviation through numerous livelihood activities. In this sense, Beijing Declaration and Platform for Action, 1995, cited in Fonchingong (2005) declared that suppression of poverty can be successfully accomplished if nations consider empowering women, especially rural women as they are the most vulnerable.

It is common practice that whenever a man loses his job in town one is bound to return home and depend on the wife's income drawn from rural livelihood activities, some of which are marginalized (Charmes, 1998 cited in Fonchingong, 2005). A field survey conducted in Chivi district of Masvingo revealed that the majority of rural women were involved in rainfed subsistence farming and horticultural production although these livelihoods are not all that sustainable 
considering that Chivi is in ecological region 4 and 5 are experiencing droughts most of the seasons (Matthew, 2003). Some women who were also interviewed in Zhara village of Chivi indicated that they were into pottery and were even seen packing their clay pots (hari) at Sese bus stop waiting to deliver them to South Africa, a foreign market (Chirau, Nkambule and Mupambwa, 2014). In a different survey conducted in Nyanyadzi area of Manicaland, Zimbabwe most of the rural women proved that they sell baskets and roasted birds (zvishiri) (PRFT, 2013). Most nations are recognizing informal trading, to which rural livelihood activities fall, as taking a stake in the economic cycle. According to Muzvidziwa (2000) a number of work force employed in the informal sector is estimated from $45-85 \%$ in developing countries, rural livelihood activities included. Rural women are contributing a lot in the rural economy through their numerous livelihood activities and their impacts manifest in providing school fees for children, food and buying household properties.

The Zimbabwe Vulnerability Assessment Committee (ZimVAC) has adopted the application of livelihoods analysis as an approach to strengthening its analysis of household vulnerability (Rigg, 2006). In November 2009, the ZimVAC conducted a livelihood rezoning exercise in all the livelihood zones in Zimbabwe (Rigg, 2006). Livelihoods in low lying areas and some mountains part of Matobo, Gwanda and Mberengwa district were found to be characterised by mainly animal husbandry and rain-fed cultivation of maize (Bryceson, 2002). It was also noted that poor rural households subsist partly on their own crop production but more importantly on cash income earned from local and cross broder employment (Cephas and Bernard, 2012). On another hand, Chirau et al. (2014) studied the Mutorashanga area with the aim of establishing rural livelihoods. It was observed that most rural households carry out informal chrome mining supplemented by gold panning, on-farm casual work, petty trade and cultivation of maize which is consumed as green cobs with very little dry harvest (Chirau et al., 2014). A lot of studies have so far been conducted in other areas of Zimbabwe relating to rural livelihoods but not in greater details in Bikita district, particularly Ward 5 (Mawere, 2014). In this study, the researcher aims to explore into the rural livelihoods for women, livelihood challenges faced and to make recommendations of possible course of action to ensure that livelihoods may be sustainable and resilient in the long term.

\section{Statement of the Problem}

Rural women in Ward 5 shoulder a lot of burdens as they are left by their husbands looking after children at home. Their situations are even worsened by the fact that Bikita district is a semi-arid region with very low rainfalls and high temperatures (Mushore, Muzenda and Makovere, 2013). This scenario has prompted rural women to shift from being domesticated to being industrious; they have since initiated livelihoods activities that can provide income and food for the wellbeing of their children (Muzvidziwa, 2000). This paper seeks to explore rural livelihoods of rural women in Ward 5 a semi-arid location, as guided by the sustainable livelihood's framework and the innovation systems approach which conceptualize the factors affecting rural livelihoods and understanding the relationships of the dynamic factors on sustainable livelihoods.

\section{Sustainable Livelihoods Framework}

This article is guided by the sustainable livelihoods framework (SLF), which helps to explain rural women livelihoods that target economic empowerment in semiarid regions of Zimbabwe. According to De Stage, Holloway, Mullins, Nchabaleng and Ward (2002) sustainable livelihoods framework is a holistic assertbased framework for understanding poverty and ways to reduce poverty. The sustainable livelihoods framework presents factors that affect the rural populace in production including the relationships between such dynamic factors. The sustainable livelihoods framework depicts people as operating in a context of vulnerability, within which they have access to certain assets. Assets gain weight and value through the prevailing social, institutional, and organizational environment (policies, institutions and processes). This context decisively shapes the livelihood strategies that are open to people in pursuit of their self-defined beneficial livelihood outcomes." (Kollmair and Gamper 2002). De Stage et al. (2002) view the sustainable livelihood framework is useful whenever there is a need to understand rural livelihoods and their sustainability. Thus, the researcher used this framework to comprehend rural livelihoods and factors affecting these livelihoods in Ward 5 of Bikita district.

\section{Gender and Livelihoods}

Gender refers to culturally defined ways of acting like a man or woman that becomes part of an individual's personal sense of self (Gandari, 
Chaminuka and Mafumbate, 2010). On another hand livelihoods are capabilities, assets and strategies that people use to make a living; that is, to achieve food and income security through a variety of economic activities (Rigg, 2006). An investigation of livelihoods in the gender context advises that different tasks are shared along the lines of socially constructed gender roles (Fuwa, 2004). Studies revealed that different socially prearranged gender roles of men and women mean that men and women have different options and responsibilities in livelihood generation process hence different options and priorities for livelihood choices (Niehof, 2004). Gender is, therefore, viewed as a factor in one's ability to access income -earning opportunities and access to natural resources (Valdiva and Gilles, 2001).

Valdiva and Gilles (2001) noted a clear gender division in livelihood activities between the men and women in Africa. In most African traditional society's men are more involved in productive labour while women are involved in reproductive labour. It is believed that production and reproduction are divisions between a monetary "productive" economy and a nonmonetary "reproductive" (Pearson, 2000). Scholars in this field often equate reproductive labour to housework or domestic labour like childcare, and care of the sick and elderly while productive labour is equated to that which is 'generative' and measurable and includes paid work, self-employment, and subsistence production. These differences are borrowed from the idea of Karl Marx and Friedrick Engels who vitalized the necessity of reproductive labour in maintaining productive labour (Khun, 2006).

Assets and the forms of capital essential to survival approaches and livelihood seem to be gendered (Valvida and Giles, 2001 in Carpenter, 2011). Those five asset classifications defined in the sustainable livelihood's framework namely, human, natural, financial, social and physical capital are achieved through investment of time and resources by individual household members. Mostly, men have greater access to each form of capital, predominantly natural, financial, and physical forms of capital (Carpenter, 2011). Such a scenario rises men's ability to diversify their livelihoods. Studies show that women increase household wellbeing as they are involved in reproductive activities (Khun, 2011). As women control economic income through their own paid employment, they effectively care for themselves and their children (Smith et al., 2003).

\section{Household Decision-Making and Livelihoods}

Decision making in the household is an important aspect of gender equality and livelihoods choice (Khun, 2006). There is ample evidence of the impact of household decision-making on development, education, poverty and the division of paid work and household work. Gender inequalities in the household reinforce, and are reinforced by, gender inequalities in society (Valdiva and Gilles, 2001). Various United Nations policy documents have therefore called for the development of programmes to address unequal decision-making power within families, and to support women's and men's joint control of household assets and joint household decision-making to guarantee adequate livelihoods for themselves and their families (United Nations, 2011). Zimbabwe Agenda for Sustainable Socio-Economic Transformation (ZimAsset) 2013-2018 focuses on improving gender equality and equity through encouraging women's participation in economic decision making and politics. However, it does not address the issues of rural women. Women do not have the same decisionmaking authority over access and ownership of assets as men. In general, men control most of the following resources and services used in performing productive activities: land, most tools and equipment, income and savings, raw material, transportation, most livestock, training and extension, farming inputs and technical agricultural information (Khun, 2006). In a typical household, husbands commonly consult with wives in making decisions on resources and benefits, but men have the final say (Khun, 2006). Within the household, women control reproductive resources such as household utensils and kitchenware.

Studies indicate that while it is common for men and women to perform many of the same productive activities, women are primarily responsible for reproductive work (Khun, 2006). According to Khun (2006) reproductive work that women and girls perform include fetching water and fuel, laundry, shopping, preparing food, cleaning the home and taking care of children and other family members. Men are involved in some reproductive roles such as making repairs to the home and collecting wood and water via scotch carts or wheelbarrows (USAID/Zimbabwe, 2012). Ministry of Agriculture, Mechanization and Irrigation Development (MAMID) (2013) noted that men in Zimbabwe make decisions on crops grown and marketed while women are responsible for ensuring food security at the household level. Although the Government of Zimbabwe acknowledges the role of women in food 
production, there has been no data on the gender dynamics in crops production. Men make decisions on the use of veterinary technologies associated with large livestock and they put more man-hours in the production of this livestock than women and children (Nyikahadzoi and Mugabe, 2015); while women have ownership and make decisions on smaller livestock such as chicken (Valdiva and Gilles, 2001).

\section{Determinants of Livelihood Diversity}

Livelihood diversity is a variety of portfolio of activities done by household members to improve their standards of living (Ellis, 2000). Rural livelihoods may become unsuitable as a result household may be forced to look for alternative sources of income in order to reduce vulnerability to various livelihood shocks (Khatun and Roy, 2012). A recent study by Food and Agriculture Organization (FAO) on farming systems and poverty has suggested that diversification is the most important source of poverty reduction for small farmers in South and South-East Asia (FAO and World Bank, 2001). Diversification of livelihoods can be affected by several factors including family size, asset value, availability of land, access and availability of irrigation facility, access to credit and ability to borrow, distance from town, training/skill development and membership of social bodies.

\section{Family Size}

Livelihood diversity is always affected by family size. Family size affects the ability of a household to supply labour to the farm (Niehof, 2004). In support of this viewpoint Ellis (2000) asserts that in a large family some members could engage in traditional farming while others could go for non-farm activities. In his own study, Ellis (2000) noted that diversification of livelihood activities in a large family will help in reducing the risks of livelihood failure. The larger the family the more the chances of livelihood diversification and vice versa.

\section{Assets Value}

Khatun and Roy (2012) observed that individuals' own asset base may help households to directly and indirectly diversify their livelihood activities. This is made possible by an understanding that assets offer a store of wealth as well as providing a strong opportunity for the asset holder to invest in alternative enterprises (Khatun and Roy, 2012). In the contrary, lack of an asset base creates an entry barrier for the resource-poor households in diversifying their livelihood choices (Ellis, 2000).

\section{Availability of Land}

Ellis (2000) regard the availability of land as central to rural livelihoods. In support of Ellis (2000) Khatun and Roy (2012) maintain that being a natural capital land is a cherished asset for poor households living in rural areas. The land is needed for agriculture, for the building of houses as a base for non-farm activities and small-scale businesses. According to Khatun and Roy (2012) lack of land tends to push rural people to diversify into alternative livelihoods that are not landbased.

\section{Access and Availability of Irrigation Facility}

Modern technologies such as irrigation and availability of irrigation facilities can assist farmers in boosting their income as well as their livelihoods (Khatun and Roy, 2012). Access to irrigation facilities means multiple harvests which provide needed food for households as well as extra that can be sold as a source of income (Khatun and Roy, 2012). It is believed that farmers can use this income to procure assets as well as invest in other activities that will bring more income into the household hence allow for diversification of livelihoods.

\section{Access to Credit and Ability to Borrow}

As rural households have access to credit and have the ability to obtain loans, they can diversify their livelihoods (Niehof, 2004). Access to credit is advantageous to a household as this provides enough capital to start up a new business or to acquire assets that can be used to advance a livelihood.

\section{Distance From Town}

Proximity to town is also a factor that affects livelihood diversification. Ellis (2000) argue that those rural households close to town are able to source markets for their produce. They also have greater chances of accessing credit facilities and loans that can further develop their livelihoods (Ellis, 2000). This entails that access to town also means access to nonfarm activities and skills that can be useful to households. In another hand being further away from town means people have no access to such facilities and reduced chances of diversifying livelihoods (Khatun and Roy, 2012).

\section{Training /Skill Development}

Human capacity is needed for households to diversify livelihood activities. Khatun and Roy (2012) view human capital as an asset required to diversify 
rural livelihoods given that diversification is easy as households attain skills (Barbier and Hochard, 2014). At the family level, the more the skills in a household, the more they can venture into different markets thereby widening their ability to make money and support their family while at an individual level, diversification in markets and ways of making a living can also aid in raising social capital and status (Khatun and Roy, 2012). Studies by Ellis (2000) indicate that better-off families can diversify more favorably than poor families as they possess the financial and social capital that is lacking in the poor families.

\section{Membership of Social Groups}

Membership to social groups within the community is one way of creating social networks (Barbier and Hochard, 2014). These networks are beneficial in obtaining knowledge that can be used to further livelihoods. According to Ellis (2000) social clubs have also been used in developing countries as ways of obtaining credit loans and as training grounds in skills that are necessary for livelihood diversification and improvement for communities in rural areas.

\section{Rural Livelihoods}

The term "livelihood" implies ways in which people satisfy their needs, or gain a living (Scoones, 2009). Scoones (2009) and Tirivangasi (2018) view all activities involved in finding food, searching for water, shelter, clothing, and all necessities required for human survival at the individual and household level as livelihoods. These livelihoods should be sufficient to avoid poverty, and preferably, increase well-being for a typical worker and his or her dependents. Schools of thought maintain that approximately $90 \%$ of rural households are involved in farming activities (Davis et al., 2010). In Africa, $70 \%$ of the household income in rural areas is from farming activities, while in Asia and Latin America, $50 \%$ of the income is from farming activities (Davis et al. 2010 cited in Bryceson, 2000). In these rural populations small-scale farming, fishing, raising livestock and non-farm activities are some of the common livelihoods that these populations survive on as a source of income (Bryceson, 2000). Bryceson (2000) noted that in Sub Saharan Africa, rural people tend to depend on natural resource-based occupations. Rural households are dependent on both cash and subsistence income including natural resource or landbased strategies such as fishing, horticulture, and livestock and harvesting (Scoones, 2009). Allison and Ellis (2001) maintain that in developing countries rural livelihoods may appear to depend mainly on natural resource base at local levels. However, studies of rural household income demonstrate that between $40 \%$ and $60 \%$ of rural income migrate from non-natural resource-based sources (Forgey et al., 2000).

In a different study conducted by Contributors Catholic Relief Services (CCRS) (2010) in Malawi, it was noted that major livelihood activities undertaken by people living in Juma district include farming, ganyu labour, fishing, and various income-generating activities such as bicycle hire, mat-making, and petty trade. In support of CCRS (2010) Gill (2003) finds out that most of the poor households in rural Malawi depend on ganyu as their chief source of income. Alternatively, some men temporarily and seasonally migrate out of the village to South Africa seeking work (Rigg, 2006). Seasonal labour migration can result from both high levels of poverty and food insecurity, a push factor and seasonal employment opportunities outside of the community/region which is a pull factor (Gill, 2003). The Zimbabwean case study indicated that most rural households depend on rain-fed subsistence farming. For example, in a study by Bird and Shepherd (2003) in semi-arid Zimbabwe, areas like Mwenezi, Gutu and Chivi, their primary livelihoods are characterised by cereal agriculture supplemented by cash cropping, animal husbandry with some remittances from migration labor. Another study of Zimbabwe's livelihood zone noted that resettled households in northern and central Zimbabwe depend on rain-fed food and cash crop cultivation (Chirau et al., 2014). These small-scale farms were allocated to settlers under the Fast-Track Land Resettlement Program that started in July 2000.

\section{METHODOLOGY}

The study was done in Bikita District of Masvingo Province, which is located about 80 kilometers east of Masvingo in Zimbabwe. The district is considered one of the driest in Masvingo Province with very low rainfalls and high temperatures. The study triangulated qualitative and quantitative approaches, to gather data. This paper adopts a qualitative research approach based on in-depth interviews to gather data on rural livelihoods, challenges faced and measures that women employ to manage the situation thereof. Quantitatively, a questionnaire was also distributed to gather data on the livelihood activities done for the selected households. Cresswell (2003) argues that qualitative studies include the various methods of inquiry such as case studies, ethnography, and observations thus they are subjective. Leedy and 
Omrod (2013) suggest that the use of triangulated methods allows the researchers to tackle problems holistically. Systematic random sampling was used to select a sample of 40 households out of 409households in Ward 5. Questionnaires were distributed at Pfupajena, Ward 5 Centre where all the households were gathered for a Care International food aid meeting. Interviews were conducted at the selected respondents' households. The study was guided by three research questions; what are the livelihood activities being done by rural women? What are the challenges being faced by rural women in their livelihood activities? What can be done to solve the challenges being faced? The qualitative data was analysed thematically while quantitative data was analysed using the Statistic Package for the Social Sciences (SPSS) software and presented using diagrams. Data was presented to answer the major questions of the study. The researchers also observed ethical issues such as confidentiality, informed consent, and voluntary participation.

\section{RESULTS AND DISCUSSION}

The researchers grouped the findings according to the themes drawn from the research questions. The paper presents data in three themes which are, livelihoods activities of women in Bikita, the challenges being faced by these women on rural livelihood options and implementation and finally the measures that can be done to ensure rural livelihoods are more productive resilient and sustainable. The ultimate purpose is to create sustainable and resilient livelihoods that can act as pathways out of poverty for rural women and may enhance women empowerment. The paper identified various challenges and prospects, and these have been discussed below.

\section{Rural Livelihoods}

The study found out that the dominant livelihood options for rural women in Bikita district include seasonal farming, selling of firewood, gardening, small livestock production, community-based money lending and saving schemes, selling of thatch grass, informal trading which includes selling of secondhand wares (mabhero) and cross-border trading, informal employment such as piece jobs (maricho) and food for work schemes (sadza basa). These livelihood options play a vital role in ensuring the well-being and provision of most people in Ward 5 of Bikita district.

Findings noted that $100 \%$ of rural women who responded to the questions depend on rain-fed subsistence farming where they grow crops like maize, groundnuts, and cowpeas mainly for household consumption and for sale if they get more than they need for consumption in an interview one respondent stressed the point when she said:

All the households in this area practice subsistence farming, each household has a plot of land where they work on like a family when the rains come. On my plot of land, I prefer to plant maize and the groundnuts, these are basic because the maize is for consumption, we cannot live without maize meal (Sadza) it constitutes a part of every meal in my house. Groundnuts are very important for making peanut butter which is used instead of cooking oil and makes the porridge for in the morning very nutritious. In good times when the rains are bountiful, we get more than enough groundnuts which we can therefore sell as peanut butter or salted nuts (mutetenegwa) by the roadside to passersby.

Subsistence farming in the area is seasonal and relies heavily on the amount of rains received each year. An in-depth interview with some of these women revealed that those living close to Biri Mountains have

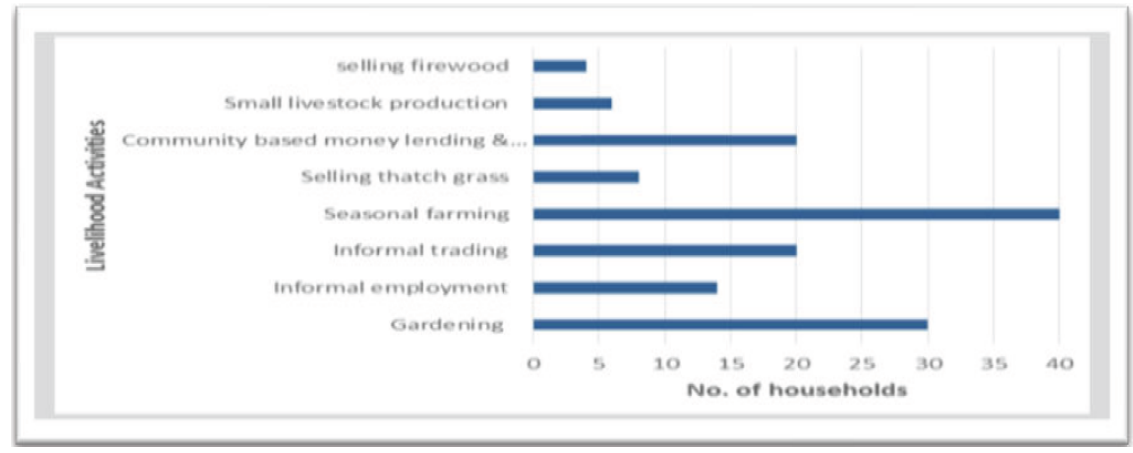

Figure 1: Rural Livelihood Activities. 
better chances of obtaining good yields since they normally receive better rains than in other areas. The study noted that most of the women in Ward 5 have their small gardens along the rivers like Tugwi, Mujiche and Chinyika. 30 households showed that they did gardening which entails the production of vegetables such as tomatoes, beans and green leafy vegetables, some for selling and some for-household consumption. Some also indicated that they have their portions in Shato and Shuro gardens, projects funded by Care International, where they grow vegetables for sale. In an interview one woman revealed that, gardens are the major sources of their relish for maize meal. In most cases they sell vegetables in the nearby growth point and schools to raise income for various needs such as sending children to school, clothes and health purposes. Most women confirmed that the success of gardens also relied heavily on the annual rainfall quantity. Most of these gardens rely on small rivers that may dry up if there are fewer rains.

Community based money lending and saving schemes (fushai) was also acknowledged by 20 households $(50 \%)$ as a livelihood activity for rural women in the ward. Those who were interviewed pointed out that they formed groups in various Village Development Committees (VIDCOs) in which group members contribute an equal amount of money and lend them money at $10 \%$ interest. However, the money is only borrowed by group members and strictly they make sure that they take turns to borrow the money and those who do not have enough money to join the groups they remain unable to benefit. In an interview one respondent said:

Fushai is very helpful to me as a woman, it is a suggested activity taught to us by a non-governmental organisation and has been running for a long time. These schemes are quite helpful in times of dire need when you are desperate for money and have nowhere else to turn to. Now as women we have also started to form in the same line as fushai, friendly groups where we agree to give one person a stipulated amount of money weekly or monthly (mukando) and the round goes until the last person has been given.

Another $50 \%$ (20 households) indicated that they raise their children through informal trading. The study found out that these women sell a variety of things like vegetables, fruits, secondhand clothes with some selling their goods as far as South Africa and Botswana. One respondent said:

I used to be able to raise income through selling of my farm produce after harvest sometimes I could get enough money to pay for school fees for my children, buy food and clothes and still have some for emergencies which would last until the next season. That was when we were receiving good rains and my children were still in primary school.

Gardening is also another source of livelihood for rural women evidenced by 30 households (75\%). Women in the area also practice gardening commonly in communally designated places where each woman has a small piece of land to grow various varieties of vegetables. The most common types are green vegetables, tomatoes, and beans. These vegetables are then sold to growth points and nearby schools to raise income for other needs. These gardens are however affected by a lack of adequate water

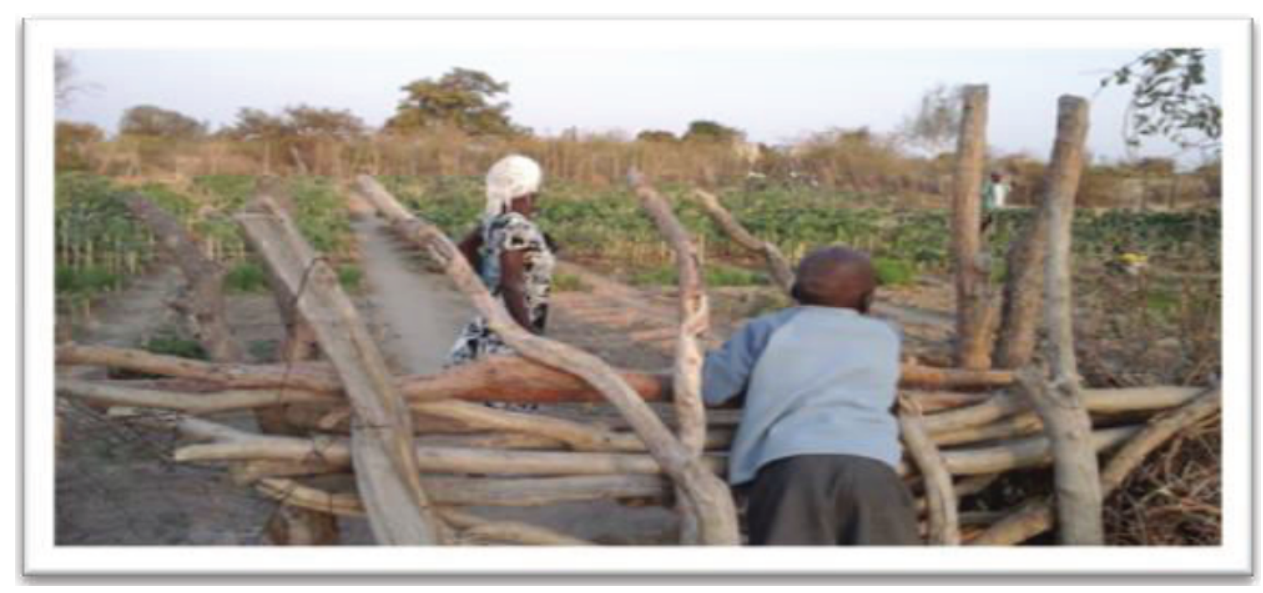

Figure 2: Community garden. 
throughout the year as some sources of water rely on the river that dries up once the rainy season is over. The picture below shows the community garden in Bikita.

It was also noted during the study that 14 households (35\%) get informal and temporary employment (maricho) to raise income. There are different types of piece jobs that are taken according to seasons of the year. During the farming season people work in other people's farms and get payed in cash or goods for their services. Some plough, weed and harvest for those in better situations. Mostly this kind of jobs is taken as a family where the whole family goes to work on the wealthier people's plot of land for payment. During off-season time, people may continue to work for other people doing some menial jobs such a digging contour, spreading of manure in the fields and preparing land for the next planting season. One woman said that:

If it were not for these small piece jobs, I would not know what I would give my children or how I would send them to school. It is a good thing because sometimes my children may help me during the weekends or after school especially during the times of weeding and harvesting.

The women in the district also embark on other livelihood options, 8 households which are $(20 \%)$ of the households surveyed sell thatch grass, 6 household $(15 \%)$ keep broiler while 4 households $(10 \%)$ earn their living from selling firewood. These are relevant forms of livelihoods and the reason why a few women choose them is because of the intense labour involved which requires both time and physical fitness for selling of firewood and thatch grass. Broiler production requires capital which most households cannot afford. The study found out that though seasonal farming is by far the most relied on source of income in the district, women have diversified their livelihoods to raise enough income for their needs.

\section{Livelihood Challenges and ways to Eradicate the Challenges}

This section deals with challenges faced by rural women in their livelihoods and what can be done to eradicate these challenges. Several factors affect rural livelihoods in Bikita district Ward 5 included (Mushore, Muzenda and Makovere, 2013). Such factors include, climate change and drought, economic crisis, access to credit facilities, siltation, and poor soils.

\section{Climate Change and Drought}

The World Bank (2006) confirms that, achieving sustainable agriculture in the impending climatic change patterns is now a major global socio-economic challenge to feeding a world population that is projected to reach 9 billion by 2050 . Given the drought challenges in the rural area of Bikita, the study asserts that, yields can be increased using accessible agricultural technologies for information systems to ensure sustainable livelihoods and women are empowered. The study noted that seasonal farming in Ward 5 of Bikita district is negatively affected by climate change which apparently results in drought. Climate change and unpredictable weather conditions pose some pressures to seasonal farming which leads to droughts because of high temperatures and low rainfalls. The findings of this study revealed that efforts should be made to effectively reduce the effects of droughts. Growing of small grain crop like sorghum, millet and rapoka was cited by most respondents as a way of eradicating the effects of drought in Ward 5 of Bikita district. These crops can assure better yields for households even under high temperatures and low rainfall although they are not a popular source of food for most households in Bikita district. Alternatively, some participants highlighted the issue of construction of dams and drilling of more boreholes as a way of providing reliable sources of water for farming. Dams and boreholes will provide water for irrigation where rural women will have to grow crops throughout the year rather than depending on rainfall which is even unpredictable given that the Bikita district is a semi-arid region.

\section{Economic Crisis}

From this study, it has been noted that the sustainability of rural livelihoods is hampered much by the economic crisis in the country. Bikita district, like any other area in the country, is hard hit by financial challenges; cash is not circulating hence even those who are involved in informal trading did not get enough capital to expand or diversify their businesses. In an interview contacted in Zvemisha village of Ward 5 respondents indicated that things were just hard for them although they were fighting hard to make ends meet. One woman exposed this when she said:

Yes, I am an informal trader selling secondhand wares from Mozambique. My customers are in rural areas where cash is a problem; they sometimes offer to pay for 
these clothes through Ecocash to which I do not have any objection considering that our current cash crisis. My major problem is that whenever I have money in my Ecocash account I have nowhere to get cash from since most Ecocash agents do not have cash saved for the few who are now giving cash at $30 \%$ rate. This means that whenever I have $\$ 100$ in my Ecocash account the agent gives me $\$ 70$. Given this scenario I cannot raise enough cash, from my sales, to have another stuff.

Respondents highlighted the issue of political stability as the only way of boosting Zimbabwean economy. Given the aspect of Ecocash, in a financially unstable economy is a form of mobile banking whose sustainability can be efficient and effective within the appropriate political-economic environment. Thus, this study confirms that given the present financial crisis in Zimbabwe, Ecocash could be an 'innovation' that if appropriately harnessed, could help maximize the possibility of sustainable livelihoods. Francis et.al. (2016), confirms that, the scale of the expansion for sustainable and innovative livelihoods can also be driven by enabling policies, regulations, banking and financial services and economic incentives. This is especially given the challenge that comes with Ecocash rates and charges.

\section{Capital}

Success with sustainable livelihoods for rural women will depend on the nature of the financial policies and institutional framework, such that, the physical and human infrastructure would enable the ease with which knowledge, financing and markets can be accessed by the women (World Bank, 2012). The researcher's experience with participants during the study revealed that most rural women lack the capital to start a meaningful business or to expand the already existing businesses. The study noted that most rural women have no access to credit facilities which can provide them with adequate capital to start or boost their intended businesses. It has been realised that credits and credit facilities may be offered by banks like the Agricultural Bank of Zimbabwe but women may lack the collateral security required to access these credit facilities. This viewpoint was exposed when a certain woman said:

Capital is my major problem; how then can I found my business? Look at me, as poor as I am I cannot get a loan from any bank because I do not have a property to present as collateral security and taking risks will put me in trouble.

In addition, the study finds out that women lack decision making powers in the home which is a great challenge as far as accessing credit facilities is concerned, they must seek their husbands' approval first. This is strengthened by the fact that most rural women have no property ownership like land ownership which may be required as collateral security. Respondents highlighted that there is a need for empowering women economically so that they can access credit facilities and realised their full potential in as much as their livelihoods are concerned. The study finds out that empowerment of rural women may help to increase their decision-making power in their households and in the community at large. Equipping women with decision-making powers will enable them to make a decision which ensures sustainable livelihoods in the absence of their husbands rather than waiting their husbands' approval. It was also noted from respondents that rural women should be accorded land ownership rights so that they can access input schemes like seeds and fertilizers for their subsistence farming as well as property right so that they can access credit facilities to fund their businesses.

\section{Poor Soils and Poor Farming Methods}

Majority of rural women in Ward 5 rely on subsistence farming as their source of livelihood. The study noted from respondents that poor soils and poor farming methods are a barrier to sustainable farming in some areas like Muziri, Nhodovari and Majecha villages where there are sandy soils. This type of soil requires fertilizers to get better yields; without applying fertilizers it will be just as good as wasting labour and seed inputs. Respondents lamented that they cannot afford the costs of buying fertilizers to apply in their fields hence they always suffer food insecurity due to poor yields. Respondents also highlighted the issue of poor farming methods by most rural farmers as threatening their livelihoods. The study finds out that some households have their gardens near riverbanks while some people are ploughing upstream which exposes the soil to agents of erosion and consequently leading to siltation of rivers which are potential sources of water for gardening. The major rivers like Tugwi and Mujiche which used to supply water for gardening have been filled with sand and water is now scarce. The community indicated that they cannot keep a watchful 
eye while their livelihoods are being menaced, instead, they suggested that there is a need for rural subsistence farmers to find means of improving their soil fertility with the aim of boosting agricultural yields if their farming is to be made sustainable. The study noted that composite manure and clay soils from antihills can be applied in the fields to improve soil structure and fertility. In another interview, the study finds out from participants that there is also a need for Agricultural Extension Officers to educate farmers on better and conservative farming methods. Conservative farming methods may help to improve soil structure as well as conserving our sources of water since siltation will be reduced to minimum.

\section{CONCLUSION}

In the study, rural women initiated numerous livelihood activities some of which were funded by Care International. Most of the households depend on rainfed subsistence farming with some surviving on petty trading like selling firewood and thatch grass. These rural livelihood activities are the major sources of food, school fees, and even provide income for building their houses. Women in Ward 5 argued that they are faced with a lot of challenges in their livelihoods. The study noted that most of the respondents highlighted that their livelihoods are affected by climate change and drought, economic crisis, lack of capital and poor soils and poor farming methods. These challenges hindered rural women from effectively providing enough for their families. However, the study finds out that the challenges of drought can be reduced by growing small grain crops like sorghum, millet or rapoko which are drought resistant. It was also noted from this study that the challenges of capital being faced by rural women can only be eradicated by empowering women so that they can access credit facilities and fund their businesses.

\section{RECOMMENDATIONS}

From the findings obtained the study, therefore, recommends that drought-resistant crops like sorghum, millet or rapoko should be grown in Ward 5 as they can assure subsistence farmers of good harvest even if they receive low rainfalls, given the dynamics of climatic change patterns. The government should empower rural women economically so that they can access credit facilities and loans from banks to have the capital for their businesses and to boost the already existing businesses. Agricultural Extension Officers should also educate farmers on how to make composite heaps so that they can use composite manure to improve their soil fertility with the aim of improving crop yields. Rural subsistence farmers should be conscientised on good farming practices like conservative farming and avoiding stream bank cultivation. Traditional leaders should desist from resettling people in mountains as this will expose vast amounts of soil to the agents of erosion and subsequently causing siltation of rivers.

\section{REFERENCES}

Barbier, E. B., \& Hochard, J. P. (2014). Poverty and the spatial distribution of rural population. Washington DC: The World Bank. https://doi.org/10.1596/1813-9450-7101

Bird, K and Shepherd, A. (2003). Livelihoods and Chronic Poverty in Semi-Arid Zimbabwe, World Development, 31 (3), 591-610. https://doi.org/10.1016/S0305-750X(02)00220-6

Bryceson, D. (2002). The scramble in Africa: Reorienting rural livelihoods. World Development, 30(5), 725-739. https://doi.org/10.1016/S0305-750X(02)00006-2

Buckland, R., Eele, G., \& Mugwara, R. (2000). Humanitarian Crisis and natural disasters, A SADC perspective, food and Humanitarian security. London: Frank Cass Production.

Carpenter, L. (2011). Livelihoods and Gender: A case study on the Coast of Southeastern Brazil. Manitoba: University of Manitoba

Cephas, M. \& Bernard, C. (2012). Effective Livelihood Strategies in Distressed Environments: The Case of Mudzi District of Zimbabwe. Journal of Social Sciences, 4(5):362-371.

Charmes, J. (1998). Informal sector, poverty and gender: A review of empirical evidence. Contributed paper for World Development Report 2000. In C.C. Fonchingong (Eds), Negotiating livelihoods beyond Beijing: the burden of women food vendors in the informal economy of Limbe, Cameroon. Oxford: Blackwell Publishing Ltd.

Chirau, T.J., Nkambule, S. \& Mupambwa, G. (2014). Rural Livelihoods in Zimbabwe: Heterogeneity, Diversification and Vulnerability. International Journal of Innovation and Applied Studies, 5(1):5-15.

Catholic Relief Services, (2010). Livelihoods in Malawi: A rapid livelihoods assessment using the Integral Human Development Conceptual Framework Assess. Baltimore: PQSD Publications.

Creswell, J. W. (2003). Research design: Quantitative, Qualitative, and Mixed methods approach (Second Edition). California. Thousand Oaks: Sage Publication.

Davis, B., Winters, P., Carletto, G., Covarrubias, K., Quiñones, E. J., Zezza, A., ... \& DiGiuseppe, S. (2010). A cross-country comparison of rural income generating activities. World development, 38(1), 48-63.

https://doi.org/10.1016/j.worlddev.2009.01.003

De Stage, R., Holloway, A., Mullins, D., Nchabaleng, L. and Ward, P. (2002). Learning about livelihoods: Insight from Southern Africa. Oxford: Oxford Publishing.

Department for International Development (DFID), (2000) Sustainable Livelihoods Guidance Sheets. http//www.livelihoods.org/info/info_guidancesheets.html (accessed 20.10.2017).

Ellis, F. (2000). Rural Livelihoods and Diversity in Developing Countries, Oxford: Oxford University Press.

Ellis, F. (2000). The determinants of rural livelihood diversification in developing countries. J Agric Econ, 51(2):289-302. https://doi.org/10.1111/j.1477-9552.2000.tb01229.x 
FAO and World Bank (2001) Farming Systems and PovertyImproving Farmer's Livelihoods in a Changing World, Rome and Washington D.C.

Fonchingong, C.C. (2005). Negotiating livelihoods beyond Beijing: the burden of women food vendors in the informal economy of Limbe, Cameroon. Oxford: Blackwell Publishing Ltd. https://doi.org/10.1111/j.1468-2451.2005.00548.x

Forgey, H. et al. (2000) South Africa survey 1999/2000. South African Institute of Race Relations Publ., Johannesburg, South Africa, 604p.

Francis, J., Mytelka, L., van Huis, A. and Röling, N. (Eds.). (2016). Innovation Systems: Towards Effective Strategies in support of Smallholder Farmers. Technical Centre for Agricultural and Rural Cooperation (CTA) and Wageningen University and Research (WUR)/Convergence of Sciences Strengthening Innovation Systems (CoS-SIS), Wageningen.

Freeman, H.A., Kaitibie, S., Moyo, S. and Perry, B.D. (2008). Livestock, livelihoods and vulnerability in Lesotho, Malawi and Zambia: Designing livestock interventions for emergence situations. ILRI, Research report 8.ILRI, Nairobi, Kenya

Fuwa, M. (2004). Macro-level gender inequality and the division of household labor in 22 countries. American Sociological Review, 69: 751- 767. https://doi.org/10.1177/000312240406900601

Gandari, E., Chaminuka, L. and Mafumbate, R. (2010). Introduction to Gender Issues in Counselling, Module BSCC 406/BEDM 404. Harare: Zimbabwe Open University.

Gills, G. (2003). Seasonal labor migration in rural Nepal: A primary overview. London: Overseas Development Institute.

International Labor Organization, (1998). Women in the informal sector and their access to microfinance. Paper presented at the Inter-Parliamentary Union (IPU) Annual Conference. Windhoek, Namibia.

Khatun, D. and Roy, B.C. (2012). Rural Livelihood Diversification in West Bengal: Determinants and Constraints, Agricultural Economics Research Review, 25(No.1), 115-124.

Khun, K. (2006). Gender issues in Cambodia. Cambodia: Royal University of Phnom Penh.

Kollmair, M. and Gamper, S. (2002). The Sustainable Livelihood Approach: Input paper for the integrated training course NCCR North South, Department of Study Group. University of Zurich.

Lamontagne, J.F., Engle, P.L. and Zeitlin, M.F. (1997). Maternal employment, childcare, and nutritional status of 12-18month-old children in Mangua, Nicaragua. Social Science and Medicine, 46(3): 403-414. https://doi.org/10.1016/S0277-9536(97)00184-6

Leedy, D. P. \& Ormrod, E. J. (2013). Practical Research: Planning and Design 10th Edition. Boston: Pearson Education.

Matthew, B. (2003). The Ownership and Management of Production. Water point Gardens in a time of Drought, Zimbabwe. International Symposium on Water, Poverty and Productive uses of Water at the Household Level, 140-154.

Mawere, M. (2014). Forest Insects, Personhood and the Environment: Harurwa (Edible Stinkbugs) and Conservation in South-Eastern Zimbabwe. Cape Town: University of Cape Town.

Ministry of Agriculture, Mechanization and Irrigation Development (MAMID). (2013). Ministry of Agriculture, Mechanization and Irrigation Development: Agricultural Sector Gender Assessment. [Report].

Mushore, T.D, Muzenda, C and Makovere, T. (2013). Effectiveness of drought mitigation strategies in Bikita District, Zimbabwe. International Journal of Environmental Protection and Policy, 1(4): 101-107. https://doi.org/10.11648/j.ijepp.20130104.19

Muzvidziwa, V. (2000). "Food vending: Adaptation under difficult circumstances", Journal of Social Development in Africa, 15(2), 69-92. https://doi.org/10.4314/jsda.v15i2.23860

Niehof, A. (2004). The significance of diversification for rural livelihood systems. Food Policy, 29: 321-338. https://doi.org/10.1016/j.foodpol.2004.07.009

Nyikahadzoi, K. \& Mugabe, P.H. (2015). A Gender Analysis of Livestock Ownership, Production, Marketing and Decision Making In Nkayi and Lupane Districts, Zimbabwe. [Draft Report]. FAO.

Perret, S. (2003). Insights into poverty and the diversity of livelihood systems in wool production communities of the Eastern Cape Province. In: Local institutional innovation and pro-poor agricultural growth: The case of small-woolgrowers' associations in South Africa (D'Haese, M. \&Vink, N, editors). Grant Publisher, Antwerp, Belgium, pp117-138.

Poverty Reduction Forum Trust, (2013). Study on rural poverty in Manicaland: The case of Mutare rural, Poverty Reduction Forum Trust: Harare, Zimbabwe.

Rigg, J. (2006). Land, Farming, Livelihoods, and Poverty: Rethinking the Links in the Rural South, World Development,34, No. 1, pp. $180-202$. https://doi.org/10.1016/j.worlddev.2005.07.015

Scoones, I. (2009). Livelihood's perspectives and rural development, The Journal of Peasant Studies, 36 (1): 171-196. https://doi.org/10.1080/03066150902820503

Tirivangasi, H. M. (2018). Regional disaster risk management strategies for food security: Probing Southern African Development Community channels for influencing national policy. Jàmbá: Journal of Disaster Risk Studies, 10(1), 1-7. https://doi.org/10.4102/jamba.v10i1.468

USAID/Zimbabwe. (2012). Gender analysis and feed the future programming.

Valdiva, C., Gilles, J. (2001). Gender and resource management: Households and groups, strategies and transition. Agriculture and Human Values, 18: 5-9. https://doi.org/10.1023/A:1007608717996

World Bank. (2006). Enhancing Agricultural Innovation: How to go Beyond the Strengthening of Research Systems. Washington, D.C: The World Bank. https://doi.org/10.1596/978-0-8213-6741-4

World Bank. (2012). Agricultural Innovation Systems: An Investment Sourcebook. Washington, D.C: The World Bank.

Received on 19-03-2021

https://doi.org/10.6000/1929-4409.2021.10.145

(c) 2021 Maramura et al.; Licensee Lifescience Global.

This is an open access article licensed under the terms of the Creative Commons Attribution Non-Commercial License (http://creativecommons.org/licenses/by-nc/3.0/) which permits unrestricted, non-commercial use, distribution and reproduction in any medium, provided the work is properly cited. 